of the Bloemfontein Town Council, chairman of the Governing Council of the National Museum, chairman of the Senate of the Grey University College, of the Senate of the University College of the Orange Free State, and chairman of the Senate of the University of South Africa. His interests extended to locust control, and he was also asked by the Provincial Authorities of the State to direct the investigation of freshwater fisheries in this province.

As time goes on, the important contributions Prof. Dreyer has made to the archæological story of South Africa and to the study of prehistoric man in this region will be more clearly seen in their true perspective and recognized for their importance. His collections have been on too great a scale for his personal complete description and publication, and will still be an important source for future research. Without them no true picture of South African prehistory is possible.

We, who were privileged to be closely associated with Prof. Dreyer, know how severely he suffered during the past two years and daily were witness to mind triumphing over body. In spite of the physical drawback, his clear memory, fast-working brain and keen interest never flagged for a moment nor deserted him. He thoroughly deserved that much-desired end -to die in harness.

A. J. D. Meiring

The passing of Prof. T. F. Dreyer has deprived the study of early man in South Africa of one of its acknowledged leaders, and his place will not be easily filled.

Outside South Africa, Prof. Dreyer will be most widely remembered as the discoverer of the Florisbad skull, the most remarkable human fossil to be found in Africa since the Broken Hill skull. This discovery was a well-deserved reward for his intuition in selecting for thorough investigation the Florisbad mineral spring deposits with their wealth of archæological and fossil mammalian remains. But his explorations in the Matjes River Cave and elsewhere also constitute notable contributions to our knowledge of man in South Africa from prehistoric to historic times.

With a characteristic scorn for the compartmenting of knowledge, Prof. Dreyer pursued his studies simultaneously in the field of physical anthropology, Quaternary mammalian palæontology, archæology and even Quaternary geology and climatology. Such a broad approach, allied to the natural vigour and freshness of his mind, gave birth to original and challenging interpretations of his discoveries. However these may fare in the light of future increases in our knowledge, there can be no doubt that to the present generation of investigators in South Africa they have been a most valuable stimulus.

Prof. Dreyer was not only distinguished in the field of research; he was also an inspiring teacher. Moreover, as a senior professor his wide-ranging and lively intelligence did valuable service both within his own University and over the whole field of university and professional education in South Africa.

The vigour with which Prof. Dreyer maintained his opinions might lead a casual reader of his writings to misconceive him as an acrimonious controversialist. To encounter him personally was to find him quite otherwise: courteous, kindly and charming. As human being as well as scholar, he will be remembered with honour and with affection.

$$
\text { L. H. WELLS }
$$

\author{
Prof. H. G. A. Hickling, F.R.S.
}

Henry George Albert Hickning, emeritus professor of geology in King's College, Newcastle upon Tyne, died on July 26 in his seventy-second year. $\mathrm{He}$ was born on April 5, 1883, in Nottingham. His school education in that town was followed by three years private study in Scotland, where the rugged cliffs of Angus were to inspire him with the love of geology. He learned the fundamentals of this science from Prof. W. Boyd Dawkins in the University of Manchester. He graduated in 1905, and after two years further study and research he became in turn lecturer in palæontology and geology in 1907 and reader in geology in 1917 in Manchester. Owing to the absence in India of Prof. T. H. (later Sir Thomas) Holland during the First World War, Hickling was acting head of the Department. In 1920 he became professor of geology in Armstrong College (now King's College), University of Durham, Newcastle upon Tyne, a post which he held until his retirement in 1948 .

In 1934 he received the Murchison Medal from the Geological Society of London and in 1936 he was elected a Fellow of the Royal Society. In 1935 he presided over Section C (Geology) of the British Association. He also served on the Council of the Geological Society, on the Geological Survey Board and on the Fuel Research Board.

His research was mainly in the fields of palæobotany, coal-measures tectonics and coal petrology. During his Manchester period he published papers on palæontology, and on the stratigraphy of the Old Red Sandstone of Angus, and a paper on the nature and origin of the Cornish china-clay, in which he advanced a new and original theory of its genesis. During the same period he made a detailed study of the tectonic structure of the Lancashire coalfield, a work published in 1924 as a coloured map of the underground contours of a single coal seam-the Trencherbone seam-supplemented in 1927 by a book, "Sections of Strata". At a later date he applied the same method of mapping to the coal seams of the Northumberland and Durham coalfield (1950).

Hickling's most striking contribution to science, and the work for which he was best known, was in the field of the study of coal. Following on the pioneering work in Great Britain of James Lomax on the micro-petrology of coal, Hickling's first paper on this subject (Trans. Inst. Min. Eng., 1917), followed by a paper on the chemical relations of the principal varieties of coal (ibid., 1927), opened up a series of publications by him and by his pupils on the microstructure and on the chemistry of coal-a new and very important contribution to coal science, and one which received world-wide recognition.

Hickling was very keen on local geology, and he was responsible for the preparation of accounts of the geology of Northumberland and Durham for the meeting of the Geologists' Association in 1931 and for the meeting of the British Association in 1949. His interest in geology as a subject of popular education was already shown in his younger days when he published his book "Geology : Chapters of Earth History", and right through his academic career he was very much appreciated as a popular lecturer. He was also interested in water supplies, a subject on which he was an acknowledged authority.

This stark enumeration of facts will not convey to the generations of students, who revered and loved him, the Prof. Hickling they knew in the lecture room, laboratory and field and whose home was 
always open to them. His clear logical exposition and the slow tempo of his speech, whether in lecture or conversation, made misunderstanding impossible, and will be as well remembered as his rapid pace as a leader of field expeditions and his speed when driving. Despite his undoubtedly important original contributions to science, it will probably be as a teacher that most people will think of him. His teaching career, covering some forty years, belonged in the main to a period when mechanical aids were fow and buildings and general equipment inadequate. In such circumstances the personality of the teacher was all in all and Prof. Hickling's innumerable past students, many of them now famous themselves, will bear witness to his pre-eminence in this respect.

His first wife (Gertrude Hermine Geiler), whom he married in 1910 and who died in 1952, was herself a medical doctor of distinction and a pioneer in the nursery-school movement, and she co-operated loyally with him. Togethor they built up a tradition of friendliness, with which, as with that of disinterested scholarship, the name of Hickling will always be associated.

S. I. TOMKEIEFF

\section{Dr. W. C. F. Shepherd}

Wilfred Charles Furness Shepherd, deputy director of the Safety in Mines Research Establishment, Sheffield, died suddenly at his home on July 19, in his fifty-second year. He had just returned from Germany after attending an International Conference of Directors of Safety in Mines Research at Dortmund.

From Manchester Grammar School, in 1919, Shepherd joined the staff of the late Prof. R. V. Wheeler at the Home Office Experimental Station, Eskmeals, Cumberland, in research on means of minimizing risks of ignition or propagation of explosions of firedamp or coal dust in mines, and devoted the whole of his working life to this purpose. $\mathrm{He}$ becarne well known in all the mining countries of the world for his research on explosives; the much greater safety of mining explosives in use in coal mining to-day in comparison with thirty years ago is an achievement of research teams of which Shepherd became a leading figure.

In his early years he was occupied with the ignition of methane by hot wires and the photographic study of movement of flame in gaseous mixtures in tubes, work related to the safety of electric and flame safety-lamps; but he soon joined the section, directed by the late W. Payman, engaged in investigations of the ignition of firedamp by mining explosives. Payman was applying schlieren photography to the study of the part played by pressure and shock waves in the ignition process and, in 1929, Shepherd was asked, under an arrangernent for the exchange of staff, to work in the laboratories of the United States Bureau of Mines. Here he made his first friends among overseas research workers, with whom he maintained an active correspondence for the rest of his life. His year and a half's study of the ignition of firedamp by explosives, by the schlieren method, was published in a Bureau Bulletin in 1932. On his return, he continued work on this subject ; many of his findings were of fundamental interest. He published two papers in the Proceedings of the Royal Society. A notable contribution was the demonstration of quasi-detonation. in methane-air mixtures under the influence of projected hot particles. He studied the ignition of gaseous mixtures by impulsive pressures produced by the bursting of diaphragms in shock tubes. $\mathrm{He}$ showed that surprisingly low pressures were sufficient to ignite mixtures of certain inflammable gases and oxygen and that ignition could even ensue from rapid expansion, that is when, for example, a methane-oxygen mixture under pressure in a tube was released into open air by the bursting of a restraining diaphragm at one end. This novel expansion-ignition phenomenon was the subject of a paper written shortly before his death. It was during this pre-war period that, with D. W. Woodhead, also in Payman's group, he developed the instrument which became known as the Buxton rotating-mirror camera.

During the war years Payman and his colleagues turned to work, under the Ministry of Supply, with military explosives, on problems relating to the detonation of shaped charges and the fragmentation of projectiles. The years 1940-45 were a period of intense activity and provided valuable experience in the development and application of new techniques. Shepherd's inventive and organizing ability assisted the team in making important contributions to armament design. Most of the work necessarily remains unpublished. 'The work for the Ministry of Supply continued after the War, and at Payman's death in 1946 Shepherd took over the direction of the team, and, at the same time, guided the reestablishment of the team devoted to research on coal-mining explosives. $\mathrm{He}$ initiated a long-term research programme and, as a more immediate practical contribution, in close collaboration with the explosives industry, he fostered the development of 'equivalent to sheathed' mining explosives in place of the sheathed explosives which were falling short of the hoped-for standard of safety. He published with H. C. Grimshaw a number of papers on these new explosives that, before his death, were meeting a third of the United Kingdom requirements.

From 1947 the responsibility for mine safety research was assumed by the Ministry of Fuel and Power, and the research of the Safety in Mines Research Establishment was expanded. Shepherd was promoted first senior principal scientific officer and then deputy chief scientific officer and became deputy director of the Establishment. He retained his interest in explosives research, and in recent years assisted in initiating research on quite new methods of blasting, convineed that the problems of mining would not be solved by research directed solely to the study of the explosives. Prompted by the disastrous fire at Creswell Colliery, he directed the formation of a new team for fire research to work on mining problems in collaboration with the Joint Fire Research Organization of the Department of Scientific and Industrial Research, and he published two authoritative papers on fire prevention. At the time of his death he was engaged in planning an important new programme of research on flame propagation and explosion prevention for the Factory Department of the Ministry of Labour and the Department of Scientific and Industrial Research.

His sudden death at the height of his powers is a serious loss to British mining research. Shepherd, though always modest and unassuming, was a man of much strength of character, who never spared himself throughout his working life. Many men in the world of mining both in the United Kingdom and in laboratories abroad will mourn his death. He leaves a widow and one daughter. H. C. Grimshaw 